\title{
EFFECTS OF PSYCHOSOCIAL STRAIN ON BACK SYMPTOMS IN TEHRAN GENERAL HOSPITAL NURSING PERSONNEL
}

\author{
Majid GOLABADI ${ }^{1}$, Mirsaeed ATTARCHI ${ }^{2}$, Saeed RAEISI ${ }^{2}$, and Mohamad NAMVAR ${ }^{2}$ \\ Vice Chancellery for Health, Isfahan University of Medical Sciences, Isfahan ${ }^{1}$, Department of Occupational Medicine, \\ Tehran University of Medical Sciences, Tehran', Iran
}

Received in May 2013

Cross Checked in May 2013

Accepted in November 2013

\begin{abstract}
Nursing is a stressful and highly demanding job. The aim of this study was to investigate the association between psychosocial job strain and the prevalence of back symptoms in nursing personnel using the demand-control model. In a cross-sectional study, 545 nursing professionals answered to a self-administered questionnaire on demography, job content, and lower and upper back symptoms (LBS and UBS, respectively). Based on their answers, the participants were grouped as follows: low strain, high strain, active job, and passive job. The groups were compared in regard to the prevalence of LBS and UBS (totalling $58.5 \%$ and $47.9 \%$, respectively) over the past 12 months. We found no association between job control and back symptoms, but participants with high psychosocial job demands showed greater risk of LBS $(\mathrm{OR}=1.57$ and $p=0.014)$ and $\mathrm{UBS}(\mathrm{OR}=1.73$ and $p=0.005)$ than those with low job demands. LBS in the low strain, high strain, and active job groups was more prevalent than in the passive group $(\mathrm{OR}=1.64$, $\mathrm{OR}=2.49$ and $\mathrm{OR}=1.90$, respectively; $p \leq 0.05)$. In addition, the high strain group showed greater prevalence of UBS than the passive group $(\mathrm{OR}=1.82$ and $p=0.019)$. Our study suggests that psychosocial job strain, high psychosocial demands in particular, may be associated with greater prevalence of back symptoms in nursing personnel. Our findings may help to design preventive measures that would lower the prevalence of musculoskeletal disorders in this profession.
\end{abstract}

KEY WORDS: lower back pain, musculoskeletal system, nurses, stress, upper back pain

Musculoskeletal disorders (MSDs) are among the most common complaints among factory workers (1, 2). The United States and Canada spend 3.1\% and $4.2 \%$, respectively for indirect costs of MSDs. Annually, billions of dollars are spent on diagnostic and therapeutic procedures related to $\operatorname{MSDs}(3,4)$. According to Caruso and Waters (5), musculoskeletal disorders are also a major cause of morbidity among healthcare workers. Trinkoff et al. (6) suggest that MSDs may be associated with increased nurse turnover. Owen (7) showed that $20 \%$ of nurses had changed their jobs at least once because of an MSD.
With a prevalence of $30 \%$ to $60 \%$, low back disorders (LBD) are the most frequent MSDs among nurses (6). About $30 \%$ of all LBDs are work-related (8), including psychosocial factors such as job strain (913).

In his demand-control model, Karasek (14) defines job strain as a combination of high psychological job demands and low job control at work. This model has extensively been used to assess psychosocial job hazard in investigations of various work-related health outcomes. The underlying principle is that workrelated stress, measured by levels of job demands and 
control (demand-control quadrants), can affect workers' health. Several studies have investigated how this interaction between job demands and job control is related to MSD development in industrial workers (15-17), but only a few have looked into the prevalence of MSDs among healthcare workers. This issue is particularly poorly covered in the nursing profession. Since nursing is a stressful, highly demanding job with low control, the aim of this study was to investigate the effects of psychosocial job strain on the prevalence of back symptoms in nursing personnel using the demand-control model.

\section{METHODS}

\section{Participants}

This cross-sectional study was conducted in 2011 and included nursing professionals (head nurses, nurses, nurses' aides, office nurses at administrative jobs, and nurse technicians) from a public hospital in Tehran, Iran with at least one year of work experience at current job. The exclusion criteria were MSDs caused by trauma or rheumatologic disorders and incomplete response to the questionnaire. Of the 695 invited participants, 587 returned the questionnaire (response rate $=84.5 \%$ ), of whom 42 were excluded based on exclusion criteria, so that data analysis included 545 questionnaires (78.4\%). All participants gave informed consent in writing and the study was approved by the ethics committee of the Tehran University of Medical Sciences.

\section{Data collection}

We used one questionnaire covering three sets of questions. The first set was used to collect personal, job, and health information (such as gender, age, marital status, education, smoking, exercise, BMI, work hours, work schedule, and history of chronic conditions and injuries to the back such as slipped disc, tendonitis, or fractures), and information on psychosocial factors and musculoskeletal symptoms. The participants were divided into day workers and shift workers. Shift work was considered work on hours other than normal daylight hours (7:00 a.m. to 6:00 p.m.) (18).

The second set corresponded to the Persian version of Karasek's Job Content Questionnaire (P-JCQ) and was used to measure psychosocial strain based on the demand-control model (14). Its reliability and validity was reported earlier by Choobineh et al. (19). Each item was scored on a four-point Likert scale (ranging from "often" to "never" or "strongly agree" to "strongly disagree"). The dataset's median of scores for psychosocial demands and job control (decision latitude) served as a cut-off to divide the participants into Karasek's job strain quadrants (14) of high or low demand and high or low control jobs and to apply these quadrants to assign each participant to their own demand-control group. The first group, called the "active job" group, is characterised by high demand and high control (usually associated with high-prestige jobs like physicians, engineers, and managers). The second, "passive job" group is characterised by low demand and low control (clerical jobs, janitors). The third, "high strain" group is characterised by high demand and low control (nurse's aides, assemblers, cutting operatives, waiters), and the fourth, "low strain" group by low demand and high control (selfpaced occupations such as repairmen and linemen) (14). Physical demand was assessed with five fourpoint-scale questions from the JCQ (body in awkward position, lifting or lowering objects/patients, bending or twisting at waist, pushing/pulling heavy objects/ patients, and standing still). For each physical item, scores one and two were considered low and scores three and four high physical demand.

The third set of questions drew from the Nordic questionnaire (20) and was related to participants' LBS and UBS experienced over the past 12 months that had disrupted their daily activities (at work and/or home). With a simple "yes" or "no" the participants were asked to answer if they had musculoskeletal symptoms such as pain, tingling sensation, numbness and stiffness, and limited movement in either the lower back or upper back area, as shown on a picture delineating the two areas.

\section{Statistical analysis}

All analyses were run with the SPSS version 11. For quantitative variables we calculated the means and standard deviations (SD). Chi-square and ANOVA tests were used to determine the distribution of all potential covariates across the job strain quadrants. Psychosocial demands groups, job control groups, and demand-control groups were compared in terms of the frequency of back symptoms. Logistic regression analysis adjusted for confounding factors was used to investigate the association between psychosocial demands, job control, and job strain with the prevalence of LBS and UBS. Quantitative variables such as age, years of work, and 
BMI were divided in two categories, using the median as a cut-off value. Smoking was divided in two categories: smokers and non-smokers. Exercise was divided in three categories: regular (at least three half-hour sessions per week), irregular, and no exercise. We also used regression analysis to test associations between gender, work schedule, and years of work (the variables that were associated with back symptoms in the main regression analyses) with back symptoms for each demand-control group. Statistical significance was set at 0.05 (two-tailed) for all tests. Odds ratios (OR) were reported with the $95 \%$ confidence interval $(95 \% \mathrm{CI})$.

\section{RESULTS}

Table 1 shows the demographic and occupational characteristics of the study participants by job strain groups. These groups did not significantly differ in gender, BMI, smoking status, or exercise. The high strain group had significantly lower mean age and years of work than the other groups $(p \leq 0.05)$. The passive job group significantly differed from the other groups in the distribution of shift and day workers $(p=0.02)$. Regarding physical demand, the frequency of awkward posture, bending/twisting at waist, and standing still, the group with the highest prevalence of either parameter significantly differed from the group with the lowest prevalence of the same parameter $(p \leq 0.05)$.

The overall prevalence of LBS was $58.5 \%$ and of UBS $47.9 \%$. Table 2 shows this prevalence by demand-control groups. The highest prevalence was observed in the high strain group $(p \leq 0.05)$. The prevalence in the high demand group was significantly higher than in the low demand group $(p \leq 0.05)$,

Table 1 Demographic and occupational characteristics by job strain groups

\begin{tabular}{|c|c|c|c|c|c|c|c|}
\hline \multirow[b]{2}{*}{ Variables } & & \multicolumn{6}{|c|}{ Job Strain Groups } \\
\hline & & $\begin{array}{c}\text { All } \\
\text { participants }\end{array}$ & $\begin{array}{c}\text { Low } \\
\text { strain } \\
(N=125)\end{array}$ & $\begin{array}{c}\text { High } \\
\text { strain } \\
(N=102)\end{array}$ & $\begin{array}{c}\text { Active } \\
\text { job } \\
(N=117)\end{array}$ & $\begin{array}{c}\text { Passive } \\
\text { job } \\
(N=\mathbf{2 0 1})\end{array}$ & $p$ \\
\hline $\operatorname{Age}^{1} /$ year & Mean $(S D)$ & $32.1(7)$ & $33.0(8.2)$ & $30.4(5.4)$ & $32.8(6.7)$ & $31.9(6.9)$ & 0.021 \\
\hline $\begin{array}{l}\text { Work experience }{ }^{1} / \\
\text { year }\end{array}$ & Mean (SD) & $8.5(6.3)$ & $10.0(7.6)$ & $6.9(5.2)$ & $8.9(6.4)$ & $8.2(5.6)$ & 0.002 \\
\hline Work experience $^{2} /$ year & & & & & & & 0.056 \\
\hline$\leq 7$ & $N(\%)$ & $304(55.8)$ & $61(48.9)$ & $68(66.7)$ & $63(53.9)$ & $112(55.7)$ & \\
\hline$>7$ & $N(\%)$ & $241(44.2)$ & $64(51.1)$ & $34(33.3)$ & $54(46.1)$ & $89(44.3)$ & \\
\hline Gender $^{2}$ & & & & & & & 0.623 \\
\hline Female & $N(\%)$ & $433(79.4)$ & $97(77.6)$ & $83(81.4)$ & $97(82.9)$ & $156(77.6)$ & \\
\hline Male & $N(\%)$ & $112(20.6)$ & $28(22.4)$ & $19(18.6)$ & $20(17.1)$ & $45(22.4)$ & \\
\hline Exercise $^{2}$ & & & & & & & 0.249 \\
\hline Yes regular & $N(\%)$ & $48(8.8)$ & $16(12.8)$ & $4(3.9)$ & $9(7.7)$ & $19(9.5)$ & \\
\hline Yes irregular & $N(\%)$ & $254(46.6)$ & $57(45.6)$ & $45(44.1)$ & $60(51.3)$ & $92(45.8)$ & \\
\hline No & $N(\%)$ & $243(44.6)$ & $52(41.6)$ & $53(52.0)$ & $48(41.0)$ & $90(44.7)$ & \\
\hline Work schedule ${ }^{2}$ & & & & & & & 0.02 \\
\hline Day Work & $N(\%)$ & $196(36.0)$ & $41(32.8)$ & $30(29.4)$ & $36(30.8)$ & $89(44.3)$ & \\
\hline Shift Work & $N(\%)$ & $349(64.0)$ & $84(67.2)$ & $72(70.6)$ & $81(69.2)$ & $112(55.7)$ & \\
\hline \multicolumn{8}{|l|}{$\begin{array}{l}\text { Physical demands }^{2} \\
\text { (High) }\end{array}$} \\
\hline Awkward posture & $\%$ & 49.5 & 40.6 & 54.4 & 59.2 & 38.5 & 0.002 \\
\hline $\begin{array}{l}\text { Lifting/lowering objects/ } \\
\text { patients }\end{array}$ & $\%$ & 35 & 33 & 36.8 & 38.5 & 29.7 & 0.512 \\
\hline Bending/twisting & $\%$ & 52.3 & 54.7 & 55.9 & 58.6 & 35.2 & 0.003 \\
\hline $\begin{array}{l}\text { Pulling/pushing objects/ } \\
\text { patients }\end{array}$ & $\%$ & 37.8 & 34.9 & 45.6 & 40.2 & 30.8 & 0.215 \\
\hline Standing still & $\%$ & 46.1 & 49.1 & 54.4 & 48.5 & 31.9 & 0.018 \\
\hline
\end{tabular}

ANOVA ${ }^{1}$ and Chi-square ${ }^{2}$ tests were used to test the differences between study groups 
Table 2 Prevalence of back symptoms by demand, control, and job strain groups

\begin{tabular}{lccccc}
\hline \multirow{2}{*}{ Variable } & Lower back & \multicolumn{2}{c}{ Upper back } \\
& Status & $\mathbf{\%}$ & $\boldsymbol{p}$ & $\mathbf{\%}$ & $\boldsymbol{p}$ \\
\hline Job control & Low & 54.8 & 0.054 & 46.5 & 0.491 \\
& High & 63.2 & & 49.6 & \\
\hline Psychosocial demands & Low & 53.1 & 0.002 & 43.3 & 0.009 \\
& High & 66.7 & & 54.8 & \\
\hline Job strain & Low Strain & 61.6 & 0.001 & 46.4 & 0.043 \\
& High Strain & 68.6 & & 56.9 & \\
& Active & 65.0 & & 53.0 & \\
& Passive & 47.8 & & 41.3 & \\
\hline
\end{tabular}

whereas in the job control groups the difference was not significant.

Table 3 shows the results of multivariate analysis of associations between demand, control, and job strain and the prevalence of back symptoms. After adjustment for confounding factors, job control showed no statistically significant associations with back symptoms, but psychosocial demands did $(p \leq 0.05)$. High psychosocial demands were associated with an increased risk of LBS and UBS. LBS was significantly more common in the low strain, high strain, and active job groups than in the passive group $(\mathrm{OR}=1.64, \mathrm{OR}=2.49$ and $\mathrm{OR}=1.90$ respectively; $p \leq 0.05)$ and UBS was significantly more common in the high strain group than in the passive group $(\mathrm{OR}=1.82$ and $p=0.019)$.

Table 4 shows that female gender, work experience of more than seven years, and shift work correlated significantly with back symptoms ( $p \leq 0.05)$. LBS and UBS were 2.63 and 2.06 times more common in women than in men $(p \leq 0.05), 3.14$ and 2.28 times more common in participants working more than seven years than those working seven years or less $(p<0.001)$, and LBS was 1.66 times more common in shift than day workers $(p=0.012)$.

Table 3 Association between back symptoms and psychosocial demands, job control, and job strain using multivariate analysis

\begin{tabular}{|c|c|c|c|c|c|c|c|}
\hline \multirow[b]{2}{*}{ Variable } & \multirow[b]{2}{*}{ Status } & \multicolumn{3}{|c|}{ Lower back } & \multicolumn{3}{|c|}{ Upper back } \\
\hline & & $\begin{array}{c}\text { Adjusted } \\
\text { OR }\end{array}$ & $95 \%$ CI & $p$ & $\begin{array}{l}\text { Adjusted } \\
\text { OR }\end{array}$ & $95 \%$ CI & $p$ \\
\hline \multirow{4}{*}{ Job strain groups } & Passive & 1.00 & - & - & 1.00 & - & - \\
\hline & Low strain & 1.64 & 1.01 to 2.66 & 0.045 & 1.14 & 0.72 to 1.81 & 0.584 \\
\hline & High strain & 2.49 & 1.46 to 4.26 & 0.001 & 1.82 & 1.10 to 3.01 & 0.019 \\
\hline & Active & 1.90 & 1.15 to 3.12 & 0.012 & 1.52 & 0.95 to 2.44 & 0.083 \\
\hline \multirow{2}{*}{ Job control } & Low & 1.00 & - & - & 1.00 & - & - \\
\hline & High & 1.21 & 0.83 to 1.76 & 0.314 & 1.01 & 0.70 to 1.43 & 0.996 \\
\hline \multirow{2}{*}{ Psychosocial demands } & Low & 1.00 & - & - & 1.00 & - & - \\
\hline & High & 1.73 & 1.18 to 2.53 & 0.005 & 1.57 & 1.09 to 2.25 & 0.014 \\
\hline \multicolumn{8}{|l|}{ Physical demands } \\
\hline \multirow{2}{*}{ Awkward posture } & Low & 1.00 & - & - & 1.00 & - & - \\
\hline & High & 2.59 & 1.61 to 4.19 & 0.000 & 2.45 & 1.57 to 3.83 & 0.000 \\
\hline \multirow{2}{*}{$\begin{array}{l}\text { Lifting/lowering objects/ } \\
\text { patients }\end{array}$} & Low & 1.00 & - & - & 1.00 & - & - \\
\hline & High & 1.15 & 0.63 to 2.11 & 0.646 & 0.83 & 0.47 to 1.47 & 0.528 \\
\hline \multirow{2}{*}{ Bending/twisting } & Low & 1.00 & - & - & 1.00 & - & - \\
\hline & High & 1.29 & 0.79 to 2.13 & 0.309 & 1.66 & 1.03 to 2.66 & 0.036 \\
\hline Pulling/pushing objects/ & Low & 1.00 & - & - & 1.00 & - & - \\
\hline patients & High & 0.98 & 0.55 to 1.74 & 0.948 & 0.99 & 0.58 to 1.69 & 0.984 \\
\hline Standing in static & Low & 1.00 & - & - & 1.00 & - & - \\
\hline position & High & 1.71 & 1.07 to 2.74 & 0.024 & 1.56 & 1.01 to 2.41 & 0.046 \\
\hline
\end{tabular}

Gender, age, BMI, smoking, exercise, work schedule, and years of work were used as confounders in the logistic regression analysis 


\section{DISCUSSION}

The main findings of our study were that nursing personnel working in low strain, high strain, and active jobs had higher prevalence of LBS than those with passive jobs and that the prevalence of UBS was significantly greater in the high strain jobs than passive jobs. Subjects working in high psychosocial demand jobs experienced more back symptoms than subjects in low demand jobs, but we found no association between job control and back symptoms. These findings suggest that decreasing psychosocial demands may lower the prevalence of back symptoms among nurses. However, this hypothesis should be confirmed by further prospective studies.

In a study by Mehrdad et al. (21), high psychosocial stress level (assessed by General Nordic Questionnaire for Psychological and Social factors at work) significantly correlated with UBS, but not with LBS. The most similar study to ours in terms of methods and results was the one by Choobineh et al. (22), who found a significant correlation between high psychological demands (established with Karasek's JCQ) and the prevalence of MSDs in operation room nurses. However, unlike all of the above mentioned studies, our study focused on the demand-control model as another viewpoint of psychosocial factors in a larger population of hospital nurses.

The demand-control model has been used to investigate the relationship between psychosocial factors and the incidence of shoulder symptoms in other professions. Smith et al. (15) found that having either a passive or high-strain job was associated with higher incidence of shoulder symptoms. The same was true for low control. Their findings are in contrast with ours, as our nurses in passive jobs had the lowest prevalence of back symptoms and only high demands were associated with back symptoms. Rugulies et al. (11) found no correlation between job strain (a combination of high psychological demands and low job control) or iso-strain (job strain plus low social support at work) and low back injuries in public transport operators. Some other studies support our findings. Ghaffari et al. (12) investigated the effect of psychosocial factors on low back pain in a cohort of 4,500 Iranian industrial workers. They found that employees with high demands, low control, job strain, low job satisfaction, and low job appreciation had increased incidence of low back pain (12). Hannan et al. (16) studied the effects of job strain and risk of musculoskeletal symptoms among occupational computer users. They concluded that workers who

Table 4 Association between gender, work experience, and shift work with back symptoms in the total population and each demand-control group separately

\begin{tabular}{|c|c|c|c|c|c|c|c|}
\hline \multirow[b]{2}{*}{ Variable } & \multirow[b]{2}{*}{ Study Group } & \multicolumn{3}{|c|}{ Lower back } & \multicolumn{3}{|c|}{ Upper back } \\
\hline & & $\begin{array}{c}\text { Adjusted } \\
\text { OR }\end{array}$ & $95 \%$ CI & $p$ & $\begin{array}{c}\text { Adjusted } \\
\text { OR }\end{array}$ & $95 \%$ CI & $p$ \\
\hline \multirow{5}{*}{$\begin{array}{l}\text { Gender } \\
\text { (Female) }\end{array}$} & All participants & 2.63 & 1.65 to 4.17 & 0.000 & 2.06 & 1.30 to 3.26 & 0.002 \\
\hline & Low strain group & 2.02 & 0.80 to 5.12 & 0.140 & 1.48 & 0.57 to 3.74 & 0.407 \\
\hline & High strain group & 2.90 & 0.94 to 8.97 & 0.064 & 0.95 & 0.31 to 2.88 & 0.926 \\
\hline & Active group & 6.89 & 1.93 to 24.57 & 0.003 & 6.35 & 1.84 to 21.99 & 0.004 \\
\hline & Passive group & 1.99 & 0.93 to 4.24 & 0.075 & 2.38 & 1.08 to 5.21 & 0.031 \\
\hline \multirow{5}{*}{$\begin{array}{l}\text { Work } \\
\text { Experience } \\
\text { (>7 years) }\end{array}$} & All participants & 3.14 & 1.97 to 5.00 & 0.000 & 2.28 & 1.46 to 3.56 & 0.000 \\
\hline & Low strain group & 1.14 & 0.41 to 3.19 & 0.809 & 1.39 & 0.51 to 3.80 & 0.519 \\
\hline & High strain group & 5.27 & 1.37 to 20.27 & 0.016 & 4.64 & 1.33 to 16.15 & 0.016 \\
\hline & Active group & 8.22 & 2.05 to 32.98 & 0.003 & 3.01 & 0.94 to 9.67 & 0.064 \\
\hline & Passive group & 3.38 & 1.71 to 6.65 & 0.000 & 2.11 & 1.09 to 4.09 & 0.027 \\
\hline \multirow{5}{*}{$\begin{array}{l}\text { Work } \\
\text { Schedule } \\
\text { (Shift Work) }\end{array}$} & All participants & 1.66 & 1.12 to 2.46 & 0.012 & 1.40 & 0.96 to 2.04 & 0.080 \\
\hline & Low strain group & 2.25 & 0.96 to 5.27 & 0.062 & 1.98 & 0.86 to 4.57 & 0.110 \\
\hline & High strain group & 1.27 & 0.45 to 3.58 & 0.649 & 2.37 & 0.89 to 6.31 & 0.084 \\
\hline & Active group & 2.45 & 0.86 to 6.96 & 0.092 & 0.89 & 0.35 to 2.27 & 0.818 \\
\hline & Passive group & 1.46 & 0.79 to 2.67 & 0.224 & 1.14 & 0.63 to 2.08 & 0.667 \\
\hline
\end{tabular}

Each variable compared with reference. The reference group for gender was male, for work experience $\leq 7$ years, and for work schedule day work

Age, BMI, smoking, and exercise were used as confounders in the logistic regression analysis 
reported high job strain were more likely to develop neck-shoulder symptoms (16). In a six years longitudinal study with 2,556 middle-aged men and women, Clays et al. (10) found that baseline low decision latitude (low control) correlated with the incidence of low back pain in men.

The National Academy of Sciences' National Research Council and Institute of Medicine (NRC/ IOM) proposed a theoretical model for the development of work-related MSDs (23). This model proposes that work-related MSDs are mainly caused by biomechanical loading (physical demands), whereas psychosocial variables may contribute to MSD development through a complex interaction with physical factors. Granata and Marras (24) showed that agonist and antagonist muscles are often coactive during lifting and moving of objects in order to stabilise the spine, and that this coactivity tends to increase the load on the spine. In a later report, Davis and Marras (25) suggest that psychosocial stressors, stress, and fatigue can significantly increase the amount of this coactivity during manual work, and therefore significantly increase spinal load compared to similar physical work under optimal conditions.

Even though shift work was associated with LBS in our study, this association was not confirmed by intra-group analysis, and we find our results inconclusive in this respect. Controversial findings of other studies only confirm that the relation between shift work and MSDs is still not clear $(5,26)$.

Our study has some limitations. The cross-sectional design limits the interpretation in terms of cause. Our study population was limited to the nursing personnel of one public hospital in the capital of Iran, which does not allow for our results to be generalised for the entire country, with a much greater job and demographic diversity. Another limitation is the healthy worker effect as our study excluded the population with back diseases caused by trauma, chronic rheumatologic disorders, and those who no longer worked due to severe symptoms. In addition, low sample size within study groups did not allow us to compare the effects of psychosocial factors between specific job groups such as head nurses, nurses, nurse's aides, office nurses, and nurse technicians.

Despite its limitations, our study has confirmed that psychosocial factors can largely contribute to the development of MSDs in the nursing personnel, and calls for a prevention programme that would help to reduce musculoskeletal problems by focusing on psychological aspects of the working environment, psychosocial demands in particular. Future research should also focus more on nursing subgroups, so that the preventive programme could address the specific issues of head nurses, nurses, nurse's aides, and so on.

\section{REFERENCES}

1. Ghasemkhani M, Mahmudi E, Jabbari H. Musculoskeletal symptoms in workers. Int J Occup Saf Ergon 2008;14:455-62. PMID: 19080050

2. Saidu IA, Utti VA, Jaiyesimi AO, Habib A, Rufa'i A, Maduagwu SM, Onuwe HA, Jajere AM. Prevalence of musculoskeletal injuries among factory workers in Kano Metropolis, Nigeria. Int J Occup Saf Ergon 2011;17:99-102. PMID: 21375958

3. Woolf AD, Pfleger B. Burden of major musculoskeletal conditions. Bull WHO 2003;81:646-56.

4. Gatchel RJ. Musculoskeletal disorders: primary and secondary interventions. J Electromyogr Kinesiol 2004;14:161-70. doi: 10.1016/j.jelekin.2003.09.007

5. Caruso CC, Waters TR. A review of work schedule issues and musculoskeletal disorders with an emphasis on the healthcare sector. Ind Health 2008;46:523-34. PMID: 19088404

6. Trinkoff AM, Lipscomb JA, Geiger-Brown J, Storr CL, Brady BA. Perceived physical demands and reported musculoskeletal problems in registered nurses. Am J Prev Med 2003;24:2705. doi: 10.1016/S0749-3797(02)00639-6

7. Owen BD. Preventing injuries using an ergonomic approach. AORN J 2000;72:1031-6. doi: 10.1016/S00012092(06)61908-X

8. Punnett L, Prüss-Utün A, Nelson DI, Fingerhut MA, Leigh J, Tak S, Phillips S. Estimating the global burden of low back pain attributable to combined occupational exposure. Am J Ind Med 2005;48:459-69. doi: 10.1002/ajim.20232

9. Vandergrift JL, Gold JE, Hanlon A, Punnett L. Physical and psychosocial ergonomic risk factors for low back pain in automobile manufacturing workers. Occup Environ Med 2012;69:29-34. doi: 10.1136/oem.2010.061770

10. Clays E, De Bacquer D, Leynen F, Kornitzer M, Kittel F, De Backer G. The impact of psychosocial factors on low back pain; longitudinal results from the Belstress study. Spine 2007;32:262-8. PMID: 17224824

11. Rugulies R, Krause N. Job strain, iso-strain, and the incidence of low back and neck injuries. A 7.5-year prospective study of San Francisco transit operators. Soc Sci Med 2005;61:2739. doi: 10.1016/j.socscimed.2004.11.042

12. Ghaffari M, Alipour A, Farshad AA, Jensen I, Josephson M, Vingard E. Effect of psychosocial factors on low back pain in industrial workers. Occup Med (Lond) 2008;58:341-7. doi: 10.1093/occmed/kqn006

13. Harcombe H, McBride D, Derrett S, Gray A. Physical and psychosocial risk factors for musculoskeletal disorders in New Zealand nurses, postal workers and office workers. Inj Prev 2010;16:96-100. doi: 10.1136/ip.2009.021766

14. Karasek R, Brisson C, Kawakami N, Houtman I, Bongers P, Amick B. The job content questionnaire (JCQ): an instrument for internationally comparative assessments of psychosocial 
job characteristics. J Occup Health Psychol 1998;3:322-55. doi: 10.1037/1076-8998.3.4.322

15. Smith CK, Silverstein BA, Fan ZJ, Bao S, Johnson PW. Psychosocial factors and shoulder symptom development among workers. Am J Ind Med. 2009;52:57-68. doi: 10.1002/ ajim. 20644

16. Hannan LM, Monteilh CP, Gerr F, Kleinbaum DG, Marcus M. Job strain and risk of musculoskeletal symptoms among a prospective cohort of occupational computer users. Scand J Work Environ Health 2005;31:375-86. doi: 10.5271/ sjweh.921

17. Leroux I, Brisson C, Montreuil S. Job strain and neckshoulder symptoms: A prevalence study of women and men white collar workers. Occup Med (Lond) 2006;56:102-9. doi: $10.1093 /$ occmed/kqj005

18. Rom WN. Environmental and Occupational Medicine. Philadelphia (PA): Lippincott Williams \& Wilkins; 2007.

19. Choobineh A, Ghaem H, Ahmedinejad P. Validity and reliability of the Persian (Farsi) version of the Job Content Questionnaire: a study among hospital nurses. East Mediterr Health J 2011;17:335-41. PMID: 22259893

20. Kuorinka I, Jonsson B, Kilbom A, Vinterberg H, BieringSørensen F, Andersson G, Jørgensen K. Standardised Nordic questionnaires for the analysis of musculoskeletal symptoms. Appl Ergon 1987;18:233-7. doi: 10.1016/00036870(87)90010-X
21. Mehrdad R, Dennerlein JT, Haghighat M, Aminian O. Association between psychosocial factors and musculoskeletal symptoms among Iranian nurses. Am J Ind Med 2010;53:10329. doi: 10.1002/ajim.20869

22. Choobineh A, Movahed M, Tabatabaie SH, Kumashiro M. Perceived demands and musculoskeletal disorders in operating room nurses of Shiraz city hospitals. Ind Health 2010;48:74-84. PMID: 20160411

23. National Research Council (NRC) and Institute of Medicine (IOM). Musculoskeletal disorders and the workplace: low back and upper extremities. Washington (DC): National Academy Press; 2001.

24. Granata KP, Marras WS. The influence of trunk muscle coactivity on dynamic spinal loads. Spine 1995;20:913-9. doi: 10.1097/00007632-199504150-00006

25. Davis KG, Marras WS. Partitioning the contributing role of biomechanical, psychosocial, and individual risk factors in the development of spine loads. Spine J 2003;3:331-8. doi: 10.1016/S1529-9430(03)00082-2

26. Sveinsdottir H. Self-assessed quality of sleep, occupational health, working environment, illness experience and job satisfaction of female nurses working different combination of shifts. Scand J Caring Sci 2006;20:229-37. PMID: 16756530 


\section{Sažetak \\ UTJECAJ PSIHOSOCIJALNIH ZAHTJEVANA NASTANAK BOLOVA U LEĐIMA U MEDICINSKIH SESTARA I TEHNIČARA OPĆE BOLNICE U TEHERANU}

Poslovi na zdravstvenoj njezi stresni su i vrlo zahtjevni. Svrha je ovog presječnog ispitivanja bila utvrditi povezanost između psihosocijalnih zahtjeva posla i prevalencije bolova u leđima u medicinskih sestara $\mathrm{i}$ tehničara prema Karasekovu modelu zahtjeva i kontrole. Analizirani su odgovori 545 njegovatelja na upitnik o demografskim podatcima, sadržaju posla te simptomima u donjem i gornjem dijelu leđa (SDL odnosno SGL). Na temelju odgovora sudionici su raspoređeni u sljedeće skupine: niski zahtjevi, visoki zahtjevi, aktivni posao i pasivni posao. Skupine su uspoređene s obzirom na prevalenciju simptoma u donjem (58,5 \%) odnosno gornjem dijelu leđa (47,9\%) u proteklih godinu dana. Nije utvrđena povezanost između kontrole i bolova u leđima, ali su sudionici s visokim psihosocijalnim zahtjevima iskazali viši rizik od nastanka simptoma u donjem dijelu leđa $(\mathrm{OR}=1,57 ; p=0,014)$ odnosno gornjem dijelu leđa $(\mathrm{OR}=1,73$; $p=0,005$ ) od sudionika s niskim zahtjevima posla. Simptomi u donjem dijelu leđa bili su učestaliji u skupinama s niskim zahtjevima, visokim zahtjevima i aktivnim poslom negoli u skupini s pasivnim poslom $(\mathrm{OR}=1,64, \mathrm{OR}=2,49$ odnosno $\mathrm{OR}=1,90 ; p \leq 0,05)$. Osim toga, skupina s visokim zahtjevima imala je veću prevalenciju simptoma u gornjem dijelu leđa od skupine s pasivnim poslom $(\mathrm{OR}=1,82 ; p=0,019)$. Rezultati ovog ispitivanja upućuju na to da poslovi s visokim psihosocijalnim zahtjevima mogu biti povezani s većim rizikom od bolova u leđima u medicinskih sestara i tehničara te pružaju korisne podatke za osmišljavanje preventivnih mjera kojima bi se smanjila prevalencija poremećaja mišićno-koštanog sustava u ovoj profesiji.

KLJUČNE RIJEČI: bol, donji dio leđa, gornji dio leđa, mišićno-koštani sustav, njegovatelji, stres

\section{CORRESPONDING AUTHOR:}

Mohamad Namvar

Tehran University of Medical Sciences, Department of Occupational Medicine Hazrat Rasoul Hospital, PO Box 14155-5983, Tehran, Iran E-mail: mohamad.namvar@gmail.com 